\title{
A Distribution and Ultrastructure of Laticifers in the Phylloclade of Euphorbia caducifolia Haines, a Potential Hydrocarbon Yielding CAM Plant
}

\author{
Bugude Rajeswari ${ }^{1}$, Sake Pradeep Kumar ${ }^{2}$, Allu Prasada Rao ${ }^{3}$, Patan Shaik Sha Valli Khan ${ }^{1^{*}}$ \\ ${ }^{1}$ Department of Botany, Yogi Vemana University, Kadapa, India; ${ }^{2}$ Department of Microbiology, Yogi Vemana University, Kadapa, \\ India; ${ }^{3}$ Department of Biotechnology, K.L University, Green Fields, Vaddeswaram, Guntur, India. \\ Email: *pssvkhan@yahoo.com
}

Received October 31 ${ }^{\text {st }}, 2013$; revised December $1^{\text {st }}, 2013$; accepted December 22 ${ }^{\text {nd }}, 2013$

Copyright (C) 2014 Bugude Rajeswari et al. This is an open access article distributed under the Creative Commons Attribution License, which permits unrestricted use, distribution, and reproduction in any medium, provided the original work is properly cited. In accordance of the Creative Commons Attribution License all Copyrights @ 2014 are reserved for SCIRP and the owner of the intellectual property Bugude Rajeswari et al. All Copyright @ 2014 are guarded by law and by SCIRP as a guardian.

\section{ABSTRACT}

The present study describes the anatomy, distribution, morphology and ultrastructure of laticifer system in the phylloclades of Euphorbia caducifolia Haines (Family Euphorbiaceae), a potential biofuel yielding, Crassulacean Acid Metabolism (CAM) plant for the first time using light and transmission electron microscopy (TEM). Histochemical tests were performed to identify the principal components of latex using a variety of stains. In cross section, the phylloclade is composed of four distinct regions: the epidermis, cortex, vascular cylinder and pith. The phylloclade anatomy indicated xeromorphic characters and provided an insight about its capacity to grow with very little rainfall and/or inputs on dry or marginal lands. Non-articulated laticifers are present in the cortex, vascular cylinder and pith, but their frequency varies with the tissue type. Highest laticifer frequency was observed in vascular cylinder $(9.6 \%)$ followed by cortex $(3.9 \%)$ and pith regions $(1.9 \%)$. In contrast, laticifer index was found to be higher in the pith $(12.7 \%)$ followed by cortex $(3.8 \%)$ and vascular cylinder $(2.3 \%)$. The discovery of a system of laticifers in $E$. caducifolia not described earlier could also be of taxonomic value. The histo-chemical tests revealed the presence of lipids, phenols, flavonoids, protein and starch in laticifer. As described by TEM observations laticifers contained distinct cell wall, nucleus and cytoplasm with ribosomes, small and big vacuoles, mitochondria, endoplasmic reticulum, plastids and osmophilic bodies. The lipophilic compounds present in the latex of this species could be used as chemical feedstock for the production of biofuels.

\section{KEYWORDS}

Biofuel; Euphorbia; Latex; Laticifer; Phylloclade; Ultrastructure

\section{Introduction}

The depletion of oil resources and the negative environmental impacts associated with fossil fuels have renewed interest for the production and use of liquid biofuels more particularly from locally available biomass feedstocks. The plants with high water use efficiency, local adaptability, drought stress tolerance and having requirement of minimum agronomic inputs are considered to be suitable biomass feedstocks for biofuel production. For example, Crassulacean Acid Metabolism (CAM) "Corresponding author. plants do not require much water, can withstand dry conditions and grow easily on marginal lands. Further, cultivating CAM plants on marginal lands for biofuel production can also have positive effect to bring some livelihood support to the farmers in rural areas. The production of biofuels from CAM plants received very less focus as source of biomass feedstock as compared to other conventional energy crops such as starch crops (e.g. corn), sugar crops (e.g. sugarcane, sugar beet), vegetable oils (soybean, canola, Jatropha, oil palm) and cellulosic crops (e.g. Miscanthus, poplar) which are well known as 
less water-efficient plants [1].

Euphorbia is one of the most diverse genera in the plant kingdom, consisting of approximately 2008 species. Many species are more or less succulent and growing mostly in the tropical and sub tropical regions of the world [2]. This genus is divided into two sub genera viz., Euphorbia and Chamaesyce based on the type of the carbon metabolism. $\mathrm{C}_{4}$ photosynthesis is restricted to the sub-genus Chamaesyce and CAM photosynthesis was observed in several species of the sub-genus Euphorbia [3]. Species like E. antiquorum Linn, E. antisyphilitica Zucc, E. lathyris Linn, E. tirucalli Linn, E. caducifolia Haines, E. neerifolia Linn and E. royleana Boiss have already been examined as potential feedstocks for biofuel production [4-7]. However, despite the fact that Euphorbia species are interesting from a biofuel, medicinal and pharmacological point of view, the majority of wild growing species of this genus are still biologically, phytochemically and pharmacologically uninvestigated.

Euphorbia caducifolia Haines is a drought resistant, succulent species with CAM photosynthesis and suitably adapted to xerophytic conditions. It varies much in its height, repeated branching and producing clumps of phylloclades. The leaves are caducous and remain on the plant for hardly few months in a year. The phylloclades are tough, fleshy and contain large mucilage cells particularly in the central portion [8]. Sticky milky latex flows out in abundance when a slight injury is caused to the phylloclade. The latex is reported to have novel phytosterols and triterpenes [9] and folk medicines for its purgative, rubefacient expectorant and antispasmodic properties [10], as well as possible biofuel [5]. Generally, the latex has also been widely understood to act as defense for the plant against generalist herbivores [11].

The latex is stored in specialized secretary tissue called laticifer. Laticifers may consist of several different single cells or a series of interconnected cells, which generally function as depositories for the intracellular excretion of terpenoids, resins, tannins, alkaloids and others [12]. Based on their mode of origin and development, two types of laticifers are recognized in plants: articulated and non-articulated laticifers [13]. Non-articulated branched laticifers have been observed in several taxa of the genus Euphorbia, developed from cells present in the embryo known as laticifers initials [12]. As the embryo grows into a matured plant, the laticifer initials elongate and undergo karyokinesis without the formation of cell plate. Thus, non-articulated laticifers become large, coenocytic cells that extend throughout the shoot and root tissues. Ultrastructure of developing and mature non-articulated laticifers had been reported by several workers in several species of Euphorbia [7,14-20]. Cytological analyses of laticifers have also been performed in several species of Euphorbia [20-22]. None of these studies have described the distribution, morphology, ultrastructure of laticifers and composition of latex in $E$. caducifolia.

Thus the main aim of this study was to examine the distribution and ultrastructure of laticifer system in phylloclades of E. caducifolia by light and transmission electron microscopy. Furthermore, histo-chemical tests were performed to identify the principal components of latex using a variety of stains and both the laticifer frequency and latex were calculated for the different regions of the phylloclade.

\section{Materials and Methods}

\subsection{Plant Material}

Young phylloclades of 2 to $3 \mathrm{~cm}$ long and approximately $2 \mathrm{~cm}$ diameter were collected from E. caducifolia (ranging from $160 \mathrm{~cm}$ to $170 \mathrm{~cm}$ height) growing on Nandimandalam forest areas of Kadapa district of Andhra Pradesh, India. Although appropriate material was available throughout the whole year, for electron microscopy the phylloclades collected exclusively in November - December months used for the description of laticifer distribution, morphology and ultrastructure.

\subsection{Anatomy of Phylloclades, Morphology and Distribution of Laticifers}

Phylloclade anatomy, morphology and laticifer distribution were observed under light microscopy. Phylloclades were cut into about $2 \mathrm{~mm}^{2}$ size and fixed in a mixture of $2 \%$ paraformaldehyde and $2.5 \%$ glutaraldehyde in $0.1 \mathrm{M}$ phosphate buffer (pH 7.4) for $12 \mathrm{~h}$ at $4^{\circ} \mathrm{C}$. Samples were washed three times in buffer and post-fixed in $1 \% \mathrm{OsO}_{4}$ for $1 \mathrm{~h}$ at $4^{\circ} \mathrm{C}$. The samples were dehydrated in ascending grades of acetone, infiltered and embedded in araldite CY 212 (TAB, UK). Ultrathin sections $(1 \mu \mathrm{m})$ were made with an ultra-microtome, fixed on to clean slides and stained with an aqueous toluidine blue $\mathrm{O}$ for phylloclade anatomy, morphology and distribution of laticifers. The stained sections were observed under $40 \times$ and photographed by a Carl Zeiss Axioscope A1 fluorescent microscope (Carl Zeiss, Germany). Images were digitalized using a CCD camera (Prog Res C3 Jenoptik).

Laticifer index (LI) and laticifer frequency (LF) were calculated based on the number of laticifer cells and undifferentiated cells under a microscopic field area $(10 \times)$. Percent laticifers were calculated as $[\mathrm{L} /(\mathrm{NL}+\mathrm{L})] \times 100$; where $\mathrm{L}$ and $\mathrm{NL}$ are the number of laticifer cells and non-laticifer cells under a microscopic field, respectively [23]. Data are the means of thirty separate observations. 


\subsection{Ultrastructure of Laticifers by Transmission Electron Microscopy (TEM)}

After gross observation of the area and quality of the tissue fixation, ultrathin sections of grey-silver colour interference (70 - $80 \mathrm{~nm}$ ) were cut and mounted on 300 mesh copper grids for transmission electron microscope observation. Sections were stained with alcoholic uranyl acetate and alkaline lead citrate, washed gently with distilled water and observed under a Morgagni 268D transmission electron microscope (Fei Company, The Netherlands) at an operating voltage $80 \mathrm{kv}$. Images were digitalized using a CCD camera (Mega view III, Fei Company).

\subsection{Histochemical Analysis}

The main components of the latex were determined on fresh hand sections of phylloclades by the following histochemical tests: 1) Sudan IV for lipids [24]; 2) Nile blue for neutral and acidic lipids [25]; 3) Ruthenium red for pectins [26] and acidic polysaccharides [27]; 4) Wagner reagent [28], Dittmar reagent [28] for alkaloids; 5) Hellram reagent and Vanillin-HCl for flavonoids [29], in particular, flavanols [30] and condensed tannins [31]; 6) Ethanol-HCl (2:1), for leucoanthocyanins and anthocyanins [32]; 7) Cresyl blue and toluidene blue for phenols and 8) Eosin for proteins [26]. The stained sections were observed under $10 \times$ and photographed by a Carl Zeiss Axioscope A1 fluorescent microscope (Carl Zeiss, Germany). Images were digitalized using a CCD camera (Prog Res C3 Jenoptik).

\section{Results}

\subsection{Anatomy of Phylloclade}

E. caducifolia possess cylindrical or sub-cylindrical branched phylloclades. In transverse section, phylloclade is exhibited three distinct regions namely: 1) cortical tissue, 2) vascular cylinder and 3) pith. The cortical region is composed of an epidermis, an outer chlorophyllous palisade-like tissue and innermost ground parenchyma. Epidermis is a single layered, covered with cuticle. The epidermal cells have thickened walls and possess conical papillae. An innermost sub-epidermal layer is formed with quadrangular and rectangular cells. Sub-epidermal cells dimensions are greater than those of typical epidermal cells. Beneath the sub-epidermal layer, chlorophyllous palisade like tissue and ground parenchyma with numerous intercellular spaces are present (Figure 1(a)). Chlorophyllous palisade layers are formed by cells perpendicularly to the surface. This tissue is composed of more than two layers occupying almost half of the cortical region (Figure 1(b)).
Palisade tissue concentrates more chloroplasts in a relatively small area of organ surface and hence considered as a specialized tissue. Directly over the vascular cylinder the ground parenchyma is formed by 2 - 5 cell layers. The ground parenchymous cells are isodiametric and thin walled in transverse section. The vascular system is collateral, radial forming a ring in which the xylem is innermost, abundant and the phloem is outermost and formed by distinctive large cells. The vascular system contains large number of xylem elements and massive radial parenchyma (Figure $\mathbf{1 ( c ) )}$. The pith comprises large irregularly shaped thin walled parenchyma cells (Figure 1(d)).

\subsection{Laticifer Distribution and Morphology}

The distribution and morphology of laticifers in phylloclades was studied under light microscope using ultrathin microtome sections. Laticifers are observed in the cortical, vascular and pith regions of phylloclade, but their frequency vary with the tissue type as shown in Table 1. The primary laticifers are distributed in the pith, vascular region and in the ground cortical parenchyma. In transverse sections, primary laticifers appeared as thick-walled rectangular cells surrounded by parenchyma cells. Primary laticifers sizes are similar to the surrounding cells, but they are conspicuous due to their dark staining contents (Figures 1(a) and (c)). However, the present study confirmed the presence of non-articulated laticifers in E. caducifolia.

Nevertheless, this study also specifically examined the laticifer distribution in three different regions of the phylloclade. This study has shown the localization of both primary and secondary laticifers in pith, vascular region, ground parenchyma and palisade tissue, respectively. Secondary laticifers are long, tube like, branched without cross-walls, non-articulated type and are limited to palisade tissue of the cortical region (Figure 1(b)). They occur either singly or occasionally paired, and are rather irregularly interspersed among the elongated cells of the palisade tissues. In addition, the cytoplasm of parenchyma cells would contain substances necessary for syntheses of sterols and triterpenes, and these substances might be conveyed to the adjacent laticifer to form latex components. Laticifers become branched commonly in $\mathrm{Y}$ configurations and establish the entire laticifer network within the phylloclade (Figure 2(d)). In this network, tips of the some laticifers was penetrated to the epidermal layer were observed (Figure 1(b)). The highest laticifer frequency was observed in the vascular cylinder (9.6\%) followed by cortex (3.9\%) and pith regions (1.9\%). In contrast laticifer index was greatest in the pith (12.7\%) followed by the cortex (3.8\%) and the vascular cylinder (2.3\%) was showed in Table 1. 

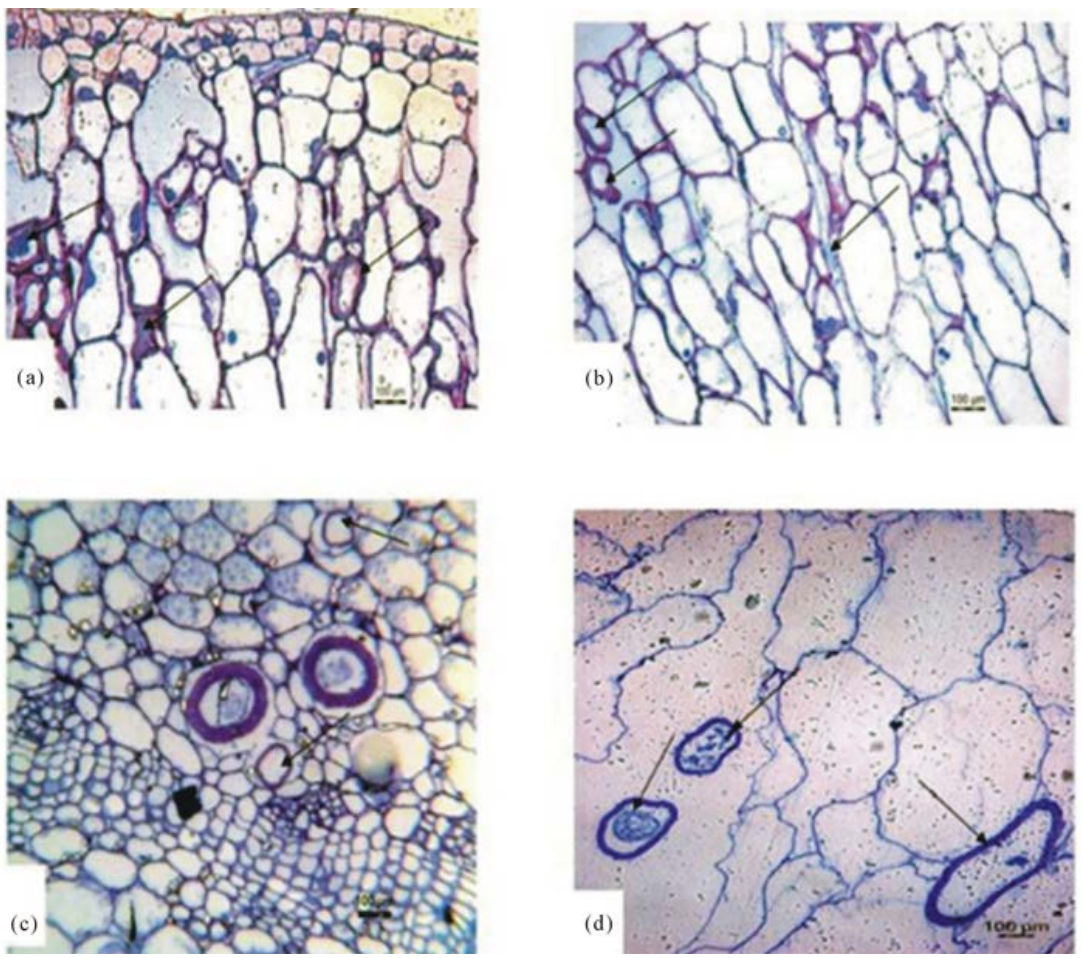

Figure 1. Laticifers in transverse section of E.caducifolia phylloclade by ultra microtome $(40 \times)$. Laticifers are interspersed between palisade tissue (arrows) stained blue with Toluidene blue $\mathrm{O}$, bars $=100 \mu \mathrm{m}(\mathrm{a}, \mathrm{b})$, laticifers are present above the vascular region (arrows), bars $=100 \mu \mathrm{m}(c)$, primary laticifers are present in pith region (arrows), bars $=100 \mu \mathrm{m}(\mathrm{d})$.
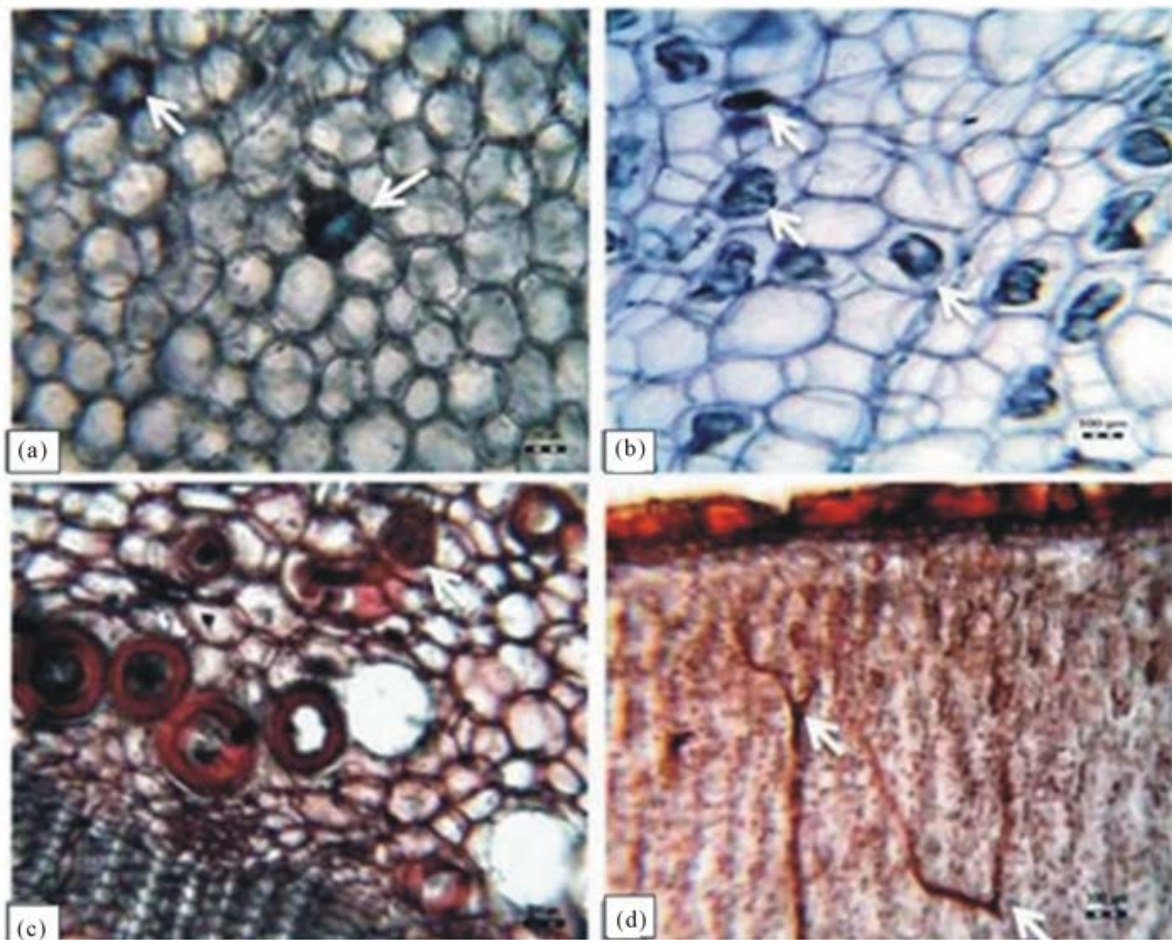

Figure 2. Histochemical tests on hand sections for laticifers $(\mathbf{1 0} \times)$. Laticifer cells in cortical cells are stained blue with Nile blue, bars $=100 \mu \mathrm{m}$ (a), laticifers stained bluish green with cresyl blue in cortical region, bars $=100 \mu \mathrm{m}(\mathrm{b})$, laticifers stained reddish brown with ruthenium red (arrows) above vascular region, bars $=100 \mu \mathrm{m}$ (c), anastomizing branch of laticifers stained orange with Sudan IV (arrows), bars $=100 \mu \mathrm{m}(\mathrm{d})$. 
Table 1. Laticifer differentiation in phylloclades of $E$. caducifolia*.

\begin{tabular}{ccc}
\hline \multirow{2}{*}{$\begin{array}{c}\text { Region of the } \\
\text { Phylloclade }\end{array}$} & \multicolumn{2}{c}{ Laticifer Differentiation } \\
\cline { 2 - 3 } & $\begin{array}{c}\text { Laticifer } \\
\text { Index (\%) }\end{array}$ & $\begin{array}{c}\text { Laticifer } \\
\text { Frequency (\%) }\end{array}$ \\
\hline Cortex & $3.8 \pm 1.4$ & $3.9 \pm 1.2$ \\
Vascular System & $2.3 \pm 0.3$ & $9.0 \pm 1.1$ \\
Pith & $12.7 \pm 0.6$ & $1.9 \pm 0.2$ \\
\hline
\end{tabular}

${ }^{*}$ Results are means \pm SD of thirty separate observations.

\subsection{Ultrastructure of Laticifer}

Results from TEM studies of laticifer and surrounding tissues revealed that laticifer ultrastructure is distinct from neighboring cells. In comparison with the neighboring cells, laticifers were well distinguished by the presence of distinctive cell wall, a prominent nucleus, dense cytoplasm rich in ribosomes, small and big vacuoles, mitochondria, plastids, endoplasmic reticulum, and osmophilic bodies (Figures 3(a) and (b)). The cell wall was thicker and darker than those of neighboring cells. A thin, dense layer of cytoplasm was confined to the periphery of the laticifer cell. The nucleus was round, sometimes elongated and lobed, the nucleoli and nuclear membrane was intact (Figure 3(a)). The mitochondria were either spherical or elongated in section with cristae and part of the envelope was unclear (Figures 3(c) and (d)). Plastids were lens-shaped and possess well-organized grana and thylakoid membrane system with a plastoglobuli was present in the homogenous stroma (Figures 3(c) and (d)). Some greatly altered plastids with a very electron-dense stroma and a series of parallel membranes were also present in the laticifer. The cytoplasm of the laticifers is comparatively rich in mitochondria than plastids.

The globular osmophilic material is present both in the large vacuoles and in the peripheral cytoplasm of the cell (Figure 3(f)). The endoplasmic reticulum presented either in long or short forms and sometimes dilated. Endoplasmic reticulum was distributed around mitochondria, plastids or globular osmophilic bodies. The dictyosomes were high in number and they secreted numerous vesicles or small vacuoles during vacuolization. The laticifers could be readily distinguished from other cells by the presence of numerous small vacuoles or vesicles (Figure 3(e)). The electron dense inclusions tended to accumulate in the vacuoles. Based on the accumulation of electron dense mass, the two types of vacuoles were recognized in laticifers: 1) small vacuoles with clear contents and, 2) big vacuoles with electron dense masses. Those with clear contents remain closely associated with cytoplasmic regions whereas vacuoles filled with dark staining contents fuse to form large central cavities. These, for some time, remain delimited by narrow sheaths of wall-lining cytoplasm.
The surrounding cells show empty vacuoles and plastids rich in starch (Figure 3(e)). From our observation, it can be speculated that these vacuoles play a key role in separating the latex droplets from the protoplasm and thus maintaining a normal metabolism. The latex particles are then transported and release into the central vacuole.

\subsection{Histochemical Tests}

Examination of phylloclade hand sections with various stains revealed differences in cytochemical properties among cell types of E. caducifolia. All cells of the phylloclade including those of laticifers were nonspecifically stained with toluidene blue $\mathrm{O}$, Nile blue (Figure 2(a)), cresyl blue (Figure 2(b)), and Dittmer stains. However, laticifers stained were more intensive than surrounding cells.

Furthermore, the intensity of staining with eosin, ruthenium red (Figure 2(c)), Sudan IV, Hellram, vanillin$\mathrm{HCl}$, ethanol-HCl stains varied with different cell types. The staining characteristics of different cell types of fresh hand sections of phylloclades are summarized in Table 2. However, the histochemical analysis of latex components in E. caducifolia has not been reported so far. It was found that phylloclade tissues were rich in fatty acids and phospholipids as confirmed by blue staining with Nile blue.

The cytoplasm of laticifers and lipid bodies in parenchyma cells surrounding laticifers and cuticle were stained orange red by Sudan IV and indicated the presence of total lipids (Figure 2(d)). All cells of the phylloclade gave strong staining reactions to cresyl blue as well as toluidine blue $\mathrm{O}$ indicating the presence of phenols. Cresyl blue stained all cells of phylloclade bluegreen and toluidine blue $\mathrm{O}$ stained all cells purple-blue except for xylem vessels, which stained blue-green. The results obtained with toluidine blue $\mathrm{O}$ indicates that cells of phylloclade walls are rich in acidic polysaccharides and phenols.

Sieve elements and laticifer cells stained light red with eosin and brick red with ruthenium red indicating the presence of protein and pectin respectively. Brick red staining with ruthenium-red indicates the presence of acid polysaccharides. Laticifers stained with Wagner reagent shows light brown colour indicate the presence of protein and starch. Further cells of phylloclade staining brown with Dittmar reagents confirm the sparse distribution of starch. The vanillin tests (Hellram test and vanillin-HCl) colored the laticifer content an intense cherry-red indicating the presence of flavonoids. Further, the thin sections were treated with ethanol-HCl, which colored anthocyanidins very light pink confirm the presence of sparse amounts of anthocyanidins. In phylloclade sections, positive reactions of colour development were not observed 

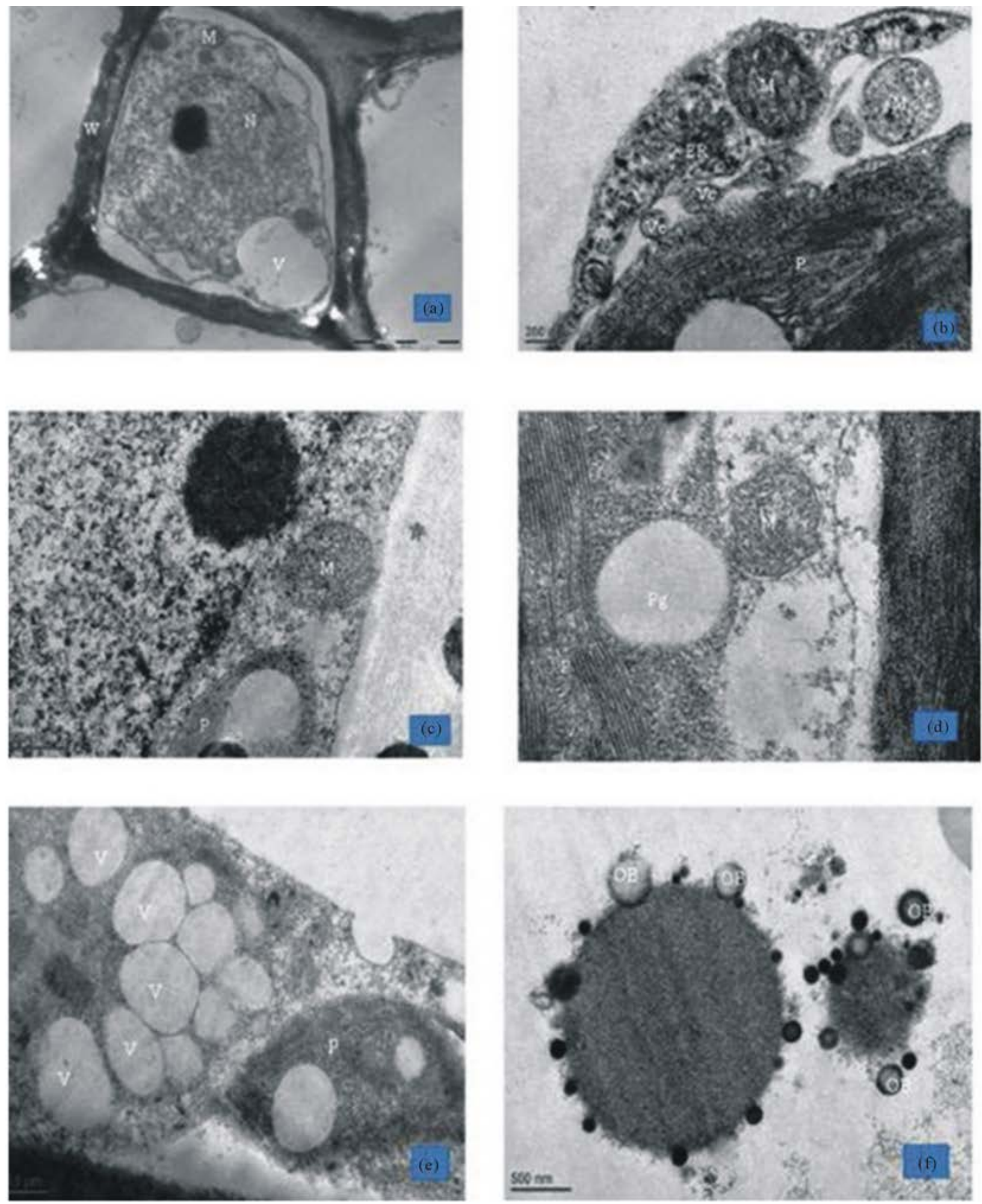

Figure 3. TEM micrographs of laticifer cells. A cytoplasmic mass (C) with nucleus (N), mitochondria (M), vacuole (V) are present and enclosed by a cell wall (W). Bars $=2 \mu \mathrm{m}(\mathrm{a})$, a swollen plastid (P), mitochondria (M) and many vesicles (Vc) originating from endoplasmic reticulum (ER) nearer to the plastid (P), bars $=200 \mathrm{~nm}(\mathrm{~b})$, plastid (P) showing stacks of grana with a plastoglobilin (Pg), bars = $500 \mathrm{~nm}(\mathrm{c})$, a swollen plastid (P) and mitochondria (M), bars = $500 \mathrm{~nm}(\mathrm{~d})$, a swollen plastid (P), numerous clear vacuoles $(\mathrm{V})$ originating in the cytoplasm, bars $=0.5 \mu \mathrm{m}(\mathrm{e})$, numerous osmophilic bodies (OB) are scattered in the cytoplasm (C), bars $=500 \mathrm{~nm}(\mathrm{f})$. 
Table 2. Staining responses of different cells of the phylloclades to histochemical tests.

\begin{tabular}{|c|c|c|c|c|}
\hline Histochemical stain & Specificity & Observed color & $\begin{array}{c}\text { Staining } \\
\text { intensity }^{\mathrm{a}}\end{array}$ & Location of stained tissue \\
\hline Cresyl blue & Phenols & Blue-green & +++ & All cells \\
\hline Toluidine blue & Phenols & Purple-blue & +++ & All cells \\
\hline Eosin & Protein & Red & + & Sieve elements and cytoplasm \\
\hline Hellram & Flavonoids & Cherry-red & ++ & Laticifer cells and xylem elements \\
\hline Vanillin-HCl & Flavonoids & Cherry-red & + & Laticifers and sieve elements \\
\hline Dittmar & Alkaloids starch & $\begin{array}{l}\text { None } \\
\text { Brown }\end{array}$ & - & All cells and intensity more for laticifers \\
\hline Ethanol -HCl & Anthocyanidins & Pink & + & Vascular elements and laticifers \\
\hline Nile blue & $\begin{array}{c}\text { Fatty acids } \\
\text { Phospho lipids neutral lipids }\end{array}$ & $\begin{array}{c}\text { Dark blue } \\
\text { Blue } \\
\text { Dark red brown }\end{array}$ & $\begin{array}{l}++++ \\
\quad+ \\
+\end{array}$ & Laticifers \\
\hline Wagner & $\begin{array}{l}\text { Cutin and suberin } \\
\text { Protein } \\
\text { Alkaloids } \\
\text { Starch }\end{array}$ & $\begin{array}{l}\text { None } \\
\text { Brown } \\
\text { None } \\
\text { Brown }\end{array}$ & $\begin{array}{l}- \\
+ \\
- \\
+\end{array}$ & Cytoplasm of all cells \\
\hline Sudan IV & Total lipids & Orange & +++ & Laticifers and cuticle \\
\hline Ruthenium red & Acid polysaccharides pectins & $\begin{array}{l}\text { Brick red } \\
\text { Brick red }\end{array}$ & $\begin{array}{l}+++ \\
+++\end{array}$ & Sieve elements \\
\hline
\end{tabular}

$\mathrm{a}_{++++}$, very strong staining; +++, strong staining; +, weak staining; -, no staining.

with regard to alkaloids (Dittmar and Dragendorff reagents).

\section{Discussion}

Euphorbia caducifolia phylloclade is a specialized vegetative character and it was considered as a plant adaptation to xeromorphic regions has been proposed for Asparagus and Myrsiphyllum [33], E. tirucalli [7] and several species of the genus Phyllanthus section Choretropsis [34]. The presence of thick cuticle and sub-epidermal layer constitutes an additional barrier against water loss from plants and it is considered to be an important xeromorphic character according to the descriptions of xeromorphic characteristics given by Fahn and Cutler [35]. The cortical cells differentiated into chlorophyllous palisade tissue and ground parenchyma with isodiametric cells. The occurrence of such palisade tissue in phylloclade has been correlated with leaf blade reduction and has also been reported to occur from Pteridophyta to Liliate [34]. The anatomy of phylloclade is in agreement with observations made in other species of the genus $[7,19]$.

Several researchers previously investigated the anatomy of some Euphorbia taxa and reported the presence of non-articulated branched laticifers [7,15,16,19,20,36,37]. However, the present study confirmed the presence of non-articulated laticifers for the first time in E. caducifolia. Nevertheless, this study also specifically examined the laticifer distribution in three different regions of the phylloclade. According to Korsmo [36] and Paliwal and
Kakkar [37], three Euphorbia species analyzed, had laticifers in leaves close to the vascular tissue, and in stems in the cortex parenchyma. E. supina stems had laticifers only in cortex was reported by Rosowski [15]. Laticifers occur throughout the vegetative parts of E. pulcherrima Willd, and are well represented in certain parenchymatous tissues and phloem [16]. The presence of laticifers in leaves near the vascular tissue and in the stem cortex parenchyma of E. nicaeensis was reported by Lukovic et al. [19].

This study has shown the localization of both primary and secondary laticifers in pith, vascular region, ground parenchyma and palisade tissue respectively. Similarly distinction between primary and secondary laticifers was also found in phylloclades of E. tirucalli [38]. These findings support the view that the new laticifers are produced in the vascular cambium [17] and extend downwards from the apex to the root, branch into leaf stalks [13], and have cytoplasmic connections to neighboring parenchyma cells. On the wounded surface of the stems, rosary-like distributed vents of latex vein associated with a reservoir tank with abundant latex components would effectively splash latex all over the wound surface and this latex would stably plug the wound surface after exposure to the air [7]. Furthermore, since the laticifer is regarded as a possible vein for oxygen transport in plants, the oxygen gas diffusion from the laticifer into neighboring parenchyma cells, if any, might provide cytoplasm of the parenchyma cell with oxygen [12,13]. Anastomoses between laticifers are believed to be involved in metabolite supply which is crucial for efficient latex 
production and to enable latex flow through the development of a network structure. Similar observations have been made in E. characias [21], E. pulcherrima [22].

The present study constitutes the first report on ultrastructure of non-articulated laticifer in E. caducifolia. The plastids, unlike those in the adjacent parenchymatous cells, did not contain starch grains [39]. Normally, the laticifers contain amyloplasts which lack membranes [40] and starch grains remain undigested even after the demolition of the organelles in the mature regions of the laticifer [16]. The observations of ultrastructure are in agreement to those reports on E. kansui [20] and Campotheca accuminata [39]. The small vacuoles in laticifers fused with each other as a result they have correlation with hydrolysis of the whole cytoplasm [16].

A unique feature of laticifers, not found in other cell types, is the accumulations of electron dense masses as reported in E. kanusi [20]. These findings suggest that the most of the latex components are synthesized in the cytoplasm and then transported to the vacuole, which is consistent with the results of a study on E. pulcherrima; this seems to be the most common model with non-articulated laticifers [16].

From our observation, it can be speculated that these vacuoles play a key role in separating the latex droplets from the protoplasm and thus maintaining a normal metabolism. The latex particles are then transported and release into the central vacuole. Similar postulate is also available for E. kansui [20]. Generally laticifers function as depositories for the intracellular excretion of latex, which is a stable dispersion (emulsion) of polymer micro particles such as terpenes, alkaloids, resins, tannins, starches, oils and gums in an aqueous medium [15]. Cytological analyses of Euphorbia plants are described in cell wall development of laticifers [41], in tube diameter [42], in membranous latex components [21] and geneexpression of enzymes for phytosterols-and triterpenebiosyntheses have been reported in levels of tissue [7].

However, the histo-chemical analysis of latex components in E. caducifolia has not been reported so far. It was found that phylloclade tissues of E. caducifolia were rich in fatty acids and phospholipids and as confirmed by blue staining by Nile blue. The distribution of both sulfated and carboxylated polysaccharides in cells of the tissue was first investigated using cationic dyes like toluidene blue $O$ [43]. The results obtained with toluidine blue $O$ indicates that cells of phylloclade walls are rich in acidic polysaccharides and phenols. These findings are consistent with the results of a study on E. pulcherrima; this seems to be the most common model in non-articulated laticifers [16]. The presence of phenols may possibly indicate that the latex plays some protective role against fungal and bacterial invasion and studies indicate that there are very high concentrations of antifungal and antibacterial substances in latex [44]. Starch is a common component of latex of several species of Euphorbiaceae [45]. Similarly, Seigler [46] recorded large number of compounds from many different classes such as flavonoids, terpenes, lipids and flavonoids from the members of the Euphorbiaceae. This finding is in accordance with the report published on Campotheca acuminate Decne [39].

\section{Conclusion}

In conclusion, this research contributes new results about phylloclade anatomy: distribution, morphology, ultrastructure of laticifers and composition of latex in E. caducifolia. Phylloclade anatomy confirmed xeromorphic characters and provided an insight about its capacity as CAM plant to grow with very little rainfall and/or inputs on dry or marginal lands. The discovery of a system of laticifers in E. caducifolia which have never been described could also be of taxonomic value. In addition, histochemical tests revealed the presence of lipophilic compounds in the phylloclades of E. caducifolia indicating that this CAM species may be useful as a biomass feedstock in arid environments.

\section{Acknowledgements}

This work was supported by financial assistance from the Department of Science and Technology, Government of India, New Delhi (DST/TSG/AF/2007/51) and Inspire programme division, Ministry of Science and Technology, Department of Science and Technology, Government of India, New Delhi. Part of this work was undertaken in the project "Biofuel production from hydrocarbon yielding plants" supported by the Department of Science and Technology, Government of India, New Delhi. The authors would like to thank SAIF-AIIMS, New Delhi for providing TEM facility for ultrastructure elucidation of laticifers.

\section{REFERENCES}

[1] L. Escamilla-Trevino, "Potential of Plants from the Genus Agave as Bioenergy Crops,” Bioenergy Research, Vol. 5, No. 1, 2012, pp. 1-9. http://dx.doi.org/10.1007/s12155-011-9159-x

[2] S. Carter, “Euphorbia,” In: U. Eggli, Ed., Dicotyledons: Illustrated Handbook of Succulent Plants, Springer, Heidelberg, 2002, p. 102.

[3] H. A. Thakur and D. A. Patil, "Taxonomic and Phylogenetic Assessment of the Euphorbiaceae," Journal of Experimental Science, Vol. 2, 2011, pp. 37-46.

[4] S. P. Mc Laughlin and J. J. Hoffmann, "Survey of Biocrude Producing Plants from the Southwest," Economic Botany, Vol. 36, No. 3, 1982, pp. 323-339. 
http://dx.doi.org/10.1007/BF02858557

[5] V. K. Bhatia, G. N. Kulsrestha, K. V. Padmaja, S. Kamara and S. D. Bhagat, "Transportation Fuels from Energy Crops,” Biomass \& Bioenergy, Vol. 4, No. 5, 1993, pp. 347-354. http://dx.doi.org/10.1016/0961-9534(93)90051-5

[6] K. V. Padmaja, N. Atheya and A. K. Bhatnagar, "Upgrading of Candelilla biocrude to Hydrocarbon Fuels by Fluid Catalytic Cracking,” Biomass \& Bioenergy, Vol. 33, 2009, pp. 1664-1669.

http://dx.doi.org/10.1016/j.biombioe.2009.08.011

[7] H. Uchida, R. Sugiyama, O. Nakayachi, M. Takemura and K. Ohyama, "Expression of the Gene for Sterol-Biosynthesis Enzyme Squalene Epoxidase in Parenchyma Cells of the Oil Plant, Euphorbia tirucalli," Planta, Vol. 226, No. 5, 2007, pp. 1109-1115. http://dx.doi.org/10.1007/s00425-007-0557-4

[8] D. N. Sen and D. D. Chawan, "Leafless Euphorbia on Rajasthan (India) Roeius,” Vegetation, Vol. 24, No. 1-3, 1972, pp. 193-214. http://dx.doi.org/10.1007/BF02387396

[9] N. Afza, A. Q. Khan, A. Malik and B. Yasmeen, “Cyclocaducinol, a Cycloratane Type Triterpene from Euphorbia caducifolia,” Phytochemistry, Vol. 28, No. 7, 1999, pp. 1982-1984. http://dx.doi.org/10.1016/S0031-9422(00)97902-0

[10] N. Afza, B. Yasmeen, A. Q. Khan, A. Malik and Q. A. Khan, "Phytochemical Investigation on the Fresh Latex of Euphorbia caducifolia,” Fitoterapia, Vol. 59, 1988, pp. 253-254.

[11] K. Konno, "Plant Latex and Other Exudates as Plant Defense Systems: Roles of Various Defense Chemicals and Proteins Contained Therein,” Phytochemistry, Vol. 72, No. 13, 2011, pp. 1510-1530. http://dx.doi.org/10.1016/S0031-9422(00)97902-0

[12] K. Esau, "Plant Anatomy,” Wiley, New York, 1967.

[13] A. Fahn, "Plant Anatomy,” Pergamon Press, Oxford, 1990.

[14] P. G. Mahlberg and P. S. Sabharwal, "Origin and Early Development of Non-Articulated Laticifers in Embryos of Euphorbia mariginata," American Journal of Botany, Vol. 55, No. 3, 1968, pp. 375-381. http://dx.doi.org/10.2307/2440424

[15] J. R. Rosowski, "Laticifer Morphology in the Mature Stem and Leaf of Euphorbia supine,” Botanical Gazette, Vol. 129, 1968, pp. 113-120. http://dx.doi.org/10.1086/336422

[16] B. A. Fineran, "Distribution and Organization of NonArticulated Laticifers in Mature Tissues of Poinsettia (Euphorbia pulcherrima Willd.)," Annals of Botany, Vol. 50, 1982, pp. 207-220.

[17] P. Rudall, "Laticifers in Crotonoidae (Euphorbiaceae) Homology and Evolution," Annals of the Missouri Botanical Garden, Vol. 81, No. 2, 1994, pp. 270-282. http://dx.doi.org/10.2307/2992097

[18] B. K. Lee and P. G. Mahlberg, "Ultrastructure and Development of Non-Articulated Laticifers in Seedlings of Euphorbia maculate L,” Journal of Plant Biology, Vol. 42, No. 1, 1999, pp. 57-62.

\section{http://dx.doi.org/10.1007/BF03031147}

[19] J. Luković, D. Malenčić, L. Zorić, B. Kiprovski, L. Merkulov and P. Boža, "Anatomical Characteristics and Antioxidant Properties of Euphorbia nicaeensis spp. Glareosa," Central European Journal of Biology, Vol. 4, No. 2, 2009, pp. 214-223. http://dx.doi.org/10.2478/s11535-009-0003-7

[20] X. Cai, W. Li and L. Yin, "Ultrastructure and Cytochemical Localization of Acid Phosphate of Laticifers in Euphorbia kansui Liou,” Protoplasma, Vol. 238, 2009, pp. 3-10. http://dx.doi.org/10.1007/s00709-009-0065-4

[21] M. F. Marty, "Vésicules Autophagiques des Laticifères Divérenciés d'Euphorbia characias L," Comptes Rendus de l'Academie des Sciences, Paris, Vol. 272, 1971, pp. 399-402.

[22] B. A. Fineran, "Differentiation of Non-Articulated Laticifers in Poinsettia (Euphorbia pulcherrima Willd.)," Annals of Botany, Vol. 52, 1983, pp. 279-293.

[23] S. S. Suri and K. G. Ramawat, "Effect of Calotropis Latex on Laticifers Differentiation in Callus Cultures of Calotropis procera,” Plant Biology, Vol. 38, No. 2, 1996, pp. 185-190. http://dx.doi.org/10.1007/BF02873844

[24] L. A. Lison, "Histochemie et Cytochemie Animales: Principles et Methods,” Gaulthier Villars, Paris, 1960.

[25] W. A. Jensen, "Botanical Histochemistry,” Freeman, San Francisco, 1962.

[26] D. A. Johansen, "Plant Microtechnique," McGraw-Hill, London, 1940.

[27] V. Amarasinghe, "Polysaccharide and Protein Secretion by Grass Micro Hairs. A Cytochemical Study at Light and Electron Microscopic Levels," Protoplasma, Vol. 156, No. 1-2, 1990, pp. 45-56. http://dx.doi.org/10.1007/BF01666505

[28] Y. Furr and P. G. Mahlberg, "Histochemical Analysis of Laticifers and Glandular Trichomes in Cannabis sativa," Journal of Natural Products, Vol. 44, No. 2, 1981, pp. 153-159. http://dx.doi.org/10.1021/np50014a002

[29] R. O. Gardner, "Vanillin-Hydrochloric Acid as a Histochemical Test for Tannin,” Stain Technology, Vol. 50, 1975, pp. 315-317.

[30] M. L. Price, S. Van Scoyoc and L.G. Butler, “A Critical Evaluation of Vanillin Reaction as an Assay for Tannin in Sorghum," Journal of Agricultural and Food Chemistry, Vol. 26, 1978, pp. 1214-1218. http://dx.doi.org/10.1021/jf60219a031

[31] S. K. Sarkar and R. E. Howarth, "Specificity of the Vanillin Test for Flavanols," Journal of Agricultural and Food Chemistry, Vol. 24, No. 2, 1976, pp. 317-320. http://dx.doi.org/10.1021/jf60204a041

[32] E. Werker, "The Secretory Cells of Pinus halepensis Mill," Israel Journal of Botany, Vol. 49, 1970, pp. 542-557.

[33] T. Fukuda, H. Ashizawa, R. Suzuki, T. Ochial, T. Nakamura, A. Kanno, T. Kameya and J. Yokoyama, "Molecular Phylogeny of the Genus Asparagus (Asparagaceae) Inferred from Plastid petB Intron and petD-rpoA Intergenic Spacer Sequences,” Plant Species Biology, Vol. 20, No. 2, 2005, pp. 121-132. 
http://dx.doi.org/10.1111/j.1442-1984.2005.00131.x

[34] L. J. M. Santiago, R. P. Louro and M. Emmerich, "Phylloclade Anatomy in Phyllanthus Section Choretropsis (Phyllanthaceae)," Botanical Journal of Linnean Society, Vol. 157, 2008, pp. 91-102. http://dx.doi.org/10.1111/j.1095-8339.2008.00780.x

[35] A. Fahn and F. D. Cutler, "Xerophytes-Encyclopedia of Plant Anatomy,” Borntraeger, Berlin, 1992.

[36] E. Korsmo, “Anatomy of Weeds: Kirstes Boktrykkeri,” Oslo, 1954.

[37] G. S. Paliwal and L. Kakkar, "Studies of the Leaf Anatomy of Euphorbia-I. Foliar Venation and Laticifers in Euphorbia thymifolia Linn. In: A. K. Ghouse and M. Yunus, Eds., Research Trend in Plant Anatomy, Tata Mc Graw-Hill Publishing Company Ltd., New Delhi, 1974.

[38] H. Uchida, K. Ohyama, M. Suzuki, H. Yamashita, Muranaka and K. Ohyama, “Triterpenoid Levels Are Reduced during Euphorbia tirucalli L. Callus Formation,” Plant Biotechnology, Vol. 27, 2010, pp. 105-109. http://dx.doi.org/10.5511/plantbiotechnology.27.105

[39] B. Monacelli, A. Valletta, N. Rascio, I. Movo and G. Pasqa, "Laticifers in Campotheca acuminate Decne: Distribution and Structure,” Protoplasma, Vol. 236, 2005, pp. 155-164. http://dx.doi.org/10.1007/s00709-005-0118-2

[40] D. Biesboer and P. G. Mahlberg, “Accumulation of NonUtilizable Starch in Laticifers of Euphorbia heterophylla and E. myrsinites," Planta, Vol. 143, No. 1, 1978, pp. 510. http://dx.doi.org/10.1007/BF00389045

[41] H. Moor, "Platin-Kohle-Abdruck-Technik Angewandt auf den Feinbau der Milchrohren," Journal of Ultrastructure Research, Vol. 2, No. 4, 1959, pp. 393-422. http://dx.doi.org/10.1016/S0022-5320(59)90003-6

[42] G. Scassellati-Sforzolini, "L’ Euphorbia tirucalli L.," Biblioteca Agrarian Colonial, Istituto Agricolo Coloniale Italiano, Firenze, 1916, pp. 1-87.

[43] K. V. Krishnamurthy, "Methods in Cell Wall Cytochemistry,” CRC Press, Boca Raton, 1999.

[44] B. Z. Hao and J. L. Wu, "Laticifer Differentiation in Hevea brasiliensis: Induction by Exogenous Jasmonic Acid and Linolenic Acid," Annals of Botany, Vol. 85, No. 1, 2000, pp. 37-43. http://dx.doi.org/10.1006/anbo.1999.0995

[45] P. G. Mahlberg, "Evolution of the Laticifer in Euphorbia as Interpreted from Starch Grain Morphology,” American Journal of Botany, Vol. 62, No. 6, 1975, pp. 577-583. http://dx.doi.org/10.2307/2441935

[46] D. S. Seigler, "Phytochemistry and Systematic of the Euphorbiaceae," Annals of the Missouri Botanical Garden, Vol. 81, No. 2, 1994, pp. 380-401. http://dx.doi.org/10.2307/2992104 